\title{
ANALISIS PENGUKURAN PASAR GASMIN BATUBARA DI DAERAH ISTIMEWA YOGYAKARTA
}

\author{
Market Measurement Analysis of Coal Gasmin in Special Region of \\ Yogyakarta
}

\author{
TRISWAN SUSENO dan IJANG SUHERMAN \\ Puslitbang Teknologi Mineral dan Batubara \\ Jalan Jenderal Sudirman 623 Bandung 40211 \\ Telp. (022) 6030483, Fax. (022) 6003373 \\ e-mail: triswan.suseno@esdm.go.id
}

\begin{abstract}
ABSTRAK
Gasifier batubara adalah alat untuk mengubah batubara menjadi bahan bakar gas yang diproses dalam suatu reaktor berukuran kecil yang dinamakan gasifikasi mini (Gasmin) batubara. Alat ini menghasilkan gas yang dapat dimanfaatkan sebagai bahan bakar di berbagai industri kecil dan menengah (IKM), dan menjadi salah satu pilihan di antara berbagai bahan bakar lain yang selama ini sudah banyak digunakan seperti kayu, solar, gas dan lain-lain. Analisis pengukuran pasar Gasmin batubara di Daerah Istimewa Yogyakarta dilakukan dengan metode analisis deskriptif melalui diskusi kelompok terfokus, wawancara disertai kuesioner, testimoni dan kunjungan ke industri yang sudah menggunakan produk ini. Penelitian ini bertujuan untuk mengukur pasar Gasmin yang berbahan bakar batubara pada IKM Daerah Istimewa Yogyakarta (DIY). Berdasarkan hasil analisis pengukuran Gasmin, diperoleh hasil: Potensi pasar sebanyak 517 unit usaha, pasar yang tersedia sebanyak 53 unit, pasar yang tersedia yang memenuhi syarat 25 unit, pasar yang dilayani atau pasar sasaran sebanyak 10 unit dan pasar yang dipenetrasi 1 unit. Analisis pengukuran pasar Gasmin ini sangat penting sebagai masukan dalam merumuskan strategi pemasaran Gasmin di DIY.
\end{abstract}

Kata kunci: IKM, Gasmin, batubara, potensi, batik.

\begin{abstract}
Coal gasifier is an equipment to convert coal into gas fuel that processed in a small reactor, called as mini coal gasification or "Gasmin". The processed gas fuel can be utilized as a fuel in various small and medium industries (IKM), becoming options among various other fuels that have been widely used such as wood, diesel, gas and others. Market measurement of Gasmin Coal in Special Region of Yogyakarta is carried out by a descriptive analysis method through focus group discussion, interview with questionnaires, testimonials and site visits to the industry who already use this product. This research aims to measure the coal-fired Gasmin market at IKM in the Special Region of Yogyakarta (DIY). Based on the Gasmin Coal measurement analysis, the following results are obtained: the market potential of 517 business units, available markets of 53 units, qualified markets of 25 units, served markets or targeted markets of 10 units and a penetrated market 1 unit. Gasmin Market measurement analysis is very important as an input for formulating the Gasmin marketing strategy in DIY.
\end{abstract}

Keywords: IKM, Gasmin, coal, food, batik.

\section{PENDAHULUAN}

Daerah Istimewa Yogyakarta merupakan salah satu wilayah dengan jumlah industri kecil dan menengah (IKM) yang cukup berkembang. Hal ini tidak terlepas dari pulihnya kegiatan ekonomi sehingga menimbulkan optimisme masyarakat. Berdasarkan data BPS (2016), 
produksi IKM di Yogyakarta pada triwulan III tahun 2016 naik 5,19\% dibandingkan triwulan yang sama tahun 2015 lalu. Lima jenis IKM yang mengalami peningkatan produksi adalah industri minuman naik $18,79 \%$, industri pakaian naik $18,7 \%$, industri percetakan dan reproduksi media rekaman naik 15,24\%, industri farmasi, produk obat kimia, obat tradisional naik $14,16 \%$ dan industri logam dasar naik 12,77 persen (BPS, 2016). Jenis industri yang mengalami pertumbuhan cukup tinggi adalah industri pengolahan tembakau yang tumbuh sebesar $12,25 \%$, industri makanan/minuman $10,16 \%$, dan industri pakaian jadi tumbuh $8,39 \%$.

Ketergantungan IKM terhadap bahan bakar gas di wilayah ini sangat tinggi, sehingga tumbuhnya IKM juga memberikan andil terhadap meningkatnya jumlah konsumsi bahan bakar ini. Setiap hari sekitar 104 tabung LPG 3 kg didistribusikan di DIY, bahkan pada momen tertentu ada pasokan fakultatif. Dengan adanya pembatasan pasokan LPG subsidi dan ketatnya persyaratan untuk mendapatkan LPG, banyak IKM sulit mendapatkannya sehingga harus membeli LPG yang non subsidi yang harganya lebih mahal, dan ini berdampak pada bertambah besarnya biaya produksi.

Bahan bakar lain yang menjadi pilihan bagi IKM adalah kayu bakar karena di wilayahwilayah tertentu di DIY kayu bakar dapat diperoleh dengan mudah dan jumlahnya pun cukup banyak. Selain mudah, harganya pun relatif murah sehingga banyak IKM yang menggunakan bahan bakar ini. Walaupun sangat hemat dalam penggunaannya namun penggunaan bahan bakar ini, dalam beberapa hal dapat merusak lingkungan yaitu adanya penebangan hutan, dan asap yang dihasilkan cukup banyak. Di samping itu, pembakaran yang dilakukan secara manual dengan menggunakan kipas akan menghasilkan panas yang tidak efektif. Tidak sedikit IKM menggunakan oli bekas yang memang bisa diperoleh dengan mudah karena di daerah ini banyak pengepul oli bekas yang siap memasok setiap saat. Oli bekas, termasuk dalam kategori Limbah Bahan Berbahaya dan Beracun (B3), hal ini dapat dilihat pada Lampiran Peraturan Pemerintah No 18 Tahun 1999. Oli bekas banyak digunakan di industri peleburan alumunium dan kalaupun ada yang menggunakan solar tetapi hanya sebagian kecil saja, karena harga solar yang dibeli adalah non subsidi yang harganya cukup mahal. Konsekuensi yang mereka hadapi apabila menggunakan oli bekas tanpa izin adalah sangsi pidana penjara atau denda yang nilainya sangat besar.

Begitu besarnya tingkat ketergantungan IKM terhadap bahan bakar, membuat mereka mencari dan mencoba berbagai bahan bakar alternatif dalam upaya menekan biaya penggunaan bahan bakar. Peluang pasar ini akan dimanfaatkan oleh Puslitbang Tekmira untuk menyosialisasikan dan memasarkan produk alternatif, yaitu Gasmin berbahan bakar batubara ke kalangan IKM. Salah satu tahapan kegiatan dalam memasarkan Gasmin adalah melakukan pengukuran pasar Gasmin. Metode pengukuran pasar Gasmin dilakukan melalui kelompok diskusi terfokus dan wawancara langsung ke lokasi IKM. Tujuannya agar dapat diketahui besarnya pasar Gasmin yang dapat dipenetrasi oleh para produsen Gasmin (company demand), sebagai dasar untuk menentukan strategi pemasaran Gasmin di DIY.

\section{TINJAUAN TEKNO EKONOMI GASMIN}

Menurut Trifiananto (2015), proses gasifikasi batubara adalah suatu pengolahan batubara yang bertujuan untuk mengkonversi secara termo-kimia batubara padat menjadi gas, sehingga mudah terbakar. Keunggulan teknologi gasifikasi batubara, antara lain :

- Dapat menghemat biaya pemakaian bahan bakar (dibanding solar) sekitar $70-80 \%$.

- Pengembalian investasi sangat singkat (pemakaian 16 jam/hari) sekitar 3-4 bulan.

- Mudah dalam pengoperasian dan tidak menimbulkan resiko / bahaya

- Tidak berbau dan ramah lingkungan

Sistem gasifikasi memiliki kelebihan dibandingkan dengan pembakaran secara langsung, karena pembakaran gas batubara jauh lebih mudah dikontrol dibanding pembakaran batubara secara langsung, sehingga menguntungkan dari segi konversi energi serta menekan polusi udara (Yusra, 2018). Keuntungan lain gasifikasi: lebih bersih, karena pembakaran lebih sempurna sehingga emisi polutan lebih rendah. Selain itu lebih mudah pengaturan laju pembakarannya. 
Teknologi gasifikasi telah banyak dimanfaatkan oleh berbagai industri dan banyak negara telah membuatnya. Salah satu di antaranya adalah Cina. Negara ini telah banyak memproduksi gasifier yang memproduksi gas bakar (menggunakan reaktor fixed-bed) dan telah diekspor termasuk ke Indonesia. Penggunaan gasifier ini di Indonesia untuk industri keramik, industri genteng, industri bata, sarung tangan, peleburan alumunium, makanan dan lain-lain (Suprapto, 2014).

Pusitbang Tekmira, sebagai salah satu lembaga penelitian terkemuka di Indonesia telah mampu memproduksi alat ini yang dinamakan gasifikasi mini atau disingkat Gasmin batubara. Produk baru ini mampu menghemat biaya energi hingga 50 persen dan ramah lingkungan (Sofaeti $d k k ., 2015$ ). Kehadirannya diharapkan menjadi alternatif untuk mengatasi permasalahan energi di kalangan IKM, sebagaimana pernyataan Marshal (2012), bahwa permasalahan yang paling umum dihadapi IKM adalah kurangnya kesadaran IKM akan pentingnya penghematan energi, penggunaan energi yang tidak efisien, keterbatasan informasi/pengetahuan tentang energi dan keterbatasan dana untuk investasi teknologi energi yang efisien. Hal itu mendorong Puslitbang Tekmira mencoba memperkenalkan dan memasarkan produk Gasmin dengan harapan produk ini dapat diterima di tengah ketatnya persaingan penggunaan energi di kalangan IKM. Sebelum dilakukan pemasaran produk Gasmin, salah satu tahap yang perlu dilakukan oleh produsen Gasmin adalah pengukuran pasar.

Pengukuran pasar adalah mengestimasi secara akurat ukuran pasar saat ini dan potensi pasar di masa depan (Wati dkk., 2013). Empat karakteristik/parameter utama yang akan diukur untuk mengetahui pasar Gasmin, yaitu minat, pendapatan, akses dan kualifikasi. Lima jenis pasar yang akan diukur adalah :

a. Pasar potensial, yaitu sekumpulan konsumen (IKM) yang memenuhi syarat untuk mengunakan Gasmin dengan kriteria padat energi, pengguna boiler, pengguna oven pengering, pengguna BBM dan gas, dan proses memasak yang kontinyu (minimal 5 jam)

b. Pasar tersedia, yaitu sekumpulan IKM yang telah memenuhi syarat sesuai kriteria pengguna Gasmin, memiliki minat, pendapatan, dan akses pada Gasmin.

c. Pasar tersedia yang memenuhi syarat, yaitu sekumpulan konsumen yang memiliki minat (Susetyarsi, 2014), pendapatan, akses dan kualifikasi untuk produk Gasmin.

d. Pasar yang dilayani atau pasar sasaran, yaitu bagian dari qualified available market yang ingin dilayani.

e. Pasar penetrasi, yaitu sekumpulan konsumen yang benar-benar telah membeli produk Gasmin.

Sarana yang digunakan untuk melakukan analisis pengukuran pasar ini adalah dengan mengadakan kelompok diskusi terfokus (focus group discussion, FGD) kepada jenis industri tertentu dan jumlah peserta tertentu dengan metode pengambilan sampel secara purposive sampling (Sugiyanto, 2017) dan berdasarkan kriteria yang telah ditetapkan (judgment sampling). Dengan kata lain, pengambilan sampel dalam sebuah populasi ditentukan berdasarkan pertimbangan tertentu. Selain melalui FGD, teknik pengumpulan data dalam penelitian ini dilakukan melalui pengamatan langsung ke lapangan atau survei ke lokasi yang menjadi objek penelitian, wawancara dengan responden menggunakan bantuan kuesioner yang telah disiapkan, seperti yang dilakukan oleh Dewanti dan Sihombing (2012). Data sekunder diperoleh dari berbagai instansi, asosiasi dan kelembagaan lainnya yang terkait. Pemilihan lokasi penelitian ditentukan berdasarkan dugaan bahwa di daerah ini terdapat populasi IKM yang menggunakan bahan bakar sebagai penunjang kegiatan produksinya.

Kriteria utama yang telah ditetapkan di atas, telah memenuhi syarat-syarat dalam menentukan sampel pada purposive sampling, yaitu:

1. Penentuan karakteristik populasi telah dilakukan dengan cermat dalam studi pendahuluan

2. Pengambilan sampel sudah berdasarkan ciri, sifat atau karakteristik tertentu yang merupakan ciri-ciri pokok populasi.

3. Subjek yang diambil sebagai sampel benarbenar subjek yang paling banyak mengandung ciri-ciri yang terdapat dalam populasi. 
Populasi dalam penelitian ini adalah seluruh IKM yang berada di Daerah Istimewa Yogyakarta, yang berjumlah 517 .

Menurut Wijayanti, Ispriyanti dan Wuryandari (2013), dalam kehidupan sehari-hari pengambilan sampel diperlukan untuk mengetahui karakteristik populasi. Dalam penelitian ini, besarnya sampel ditentukan dengan menggunakan rumus slovin, jumlahnya sebanyak 115 pengusaha.

Teknik pengumpulan data dan informasi berikutnya adalah memberikan formulir pengisian dalam bentuk kuesioner yang didalamnya telah disusun pertanyaanpertanyaan tertulis yang diberikan kepada responden untuk dijawab. Pertanyaan yang disusun bertujuan untuk mengetahui minat dan kemampuan konsumen untuk membeli produk serta pandangan konsumen terhadap produk yang ditawarkan. Hasil rekapitulasi jawaban dalam kuesioner kemudian ditindaklanjuti dengan mendatangi responden ke rumah atau lokasi usaha mereka. Dengan menggunakan metode ini, dapat diketahui jumlah responden yang berminat atau pun tidak sehingga bisa diperkirakan jumlah responden yang akan membeli produk Gasmin batubara. Data penelitian diperoleh dari hasil pengisian formulir pertanyaan yang disebarkan sesudah diberikan pengetahuan tentang Gasmin batubara dan hasil kunjungan ke beberapa IKM yang telah menggunakan Gasmin batubara.

Pangsa pasar Gasmin batubara dipilih berdasarkan kriteria dari karakteristik produk Gasmin itu sendiri. Data tersebut diperoleh dari hasil pemilihan yang dilakukan oleh Dinas Perindustrian, Koperasi dan UMKM dari masing-masing kota dan kabupaten di DIY, sedangkan pasar yang terpenetrasi diperoleh berdasarkan persepsi dan ketertarikan responden untuk membeli produk Gasmin batubara. Menurut Rakhman (2016), produk adalah segala sesuatu yang dapat ditawarkan di pasar, yang nantinya akan dibeli oleh konsumen dan dapat memberikan manfaat bagi konsumen, yang nantinya akan menghasilkan kepuasan tersendiri bagi pengguna produk tersebut (Adawiyah, 2012). Oleh karena itu, dalam pemilihan responden yang akan dijadikan objek penelitian ditentukan berdasarkan pertimbangan tertentu (purposive sampling). Dalam penelitian ini, untuk pemilihan IKM yang akan dijadikan objek penelitian ditentukan berdasarkan kriteria sebagai berikut:

1. Padat energi

2. Pengguna boiler

3. Pengguna oven pengering

4. Pengguna BBM dan gas

5. Proses memasak yang kontinyu (minimal 5 jam)

Hal ini dilakukan untuk mendapatkan responden yang benar-benar tepat untuk menjawab setiap pertanyaan dalam kuesioner (Pebriani, 2016).

\section{METODE}

\section{Populasi IKM}

Menurut Dinas Perindustrian dan Perdagangan Daerah Istimewa Yogyakarta (2017), jumlah industri kecil dan menengah (IKM) di daerah ini sekitar 51.387 unit. Jumlah tersebut terdiri dari berbagai jenis industri, 35,60 \% IKM tersebar di Kabupaten Bantul, 30,84\% terletak di Kabupaten Sleman, Kota Yogya sekitar $12,68 \%$, Gunung Kidul 10,74\% dan Kulon Progo 10,13\% (Gambar 1).

Gasmin adalah suatu alat penghasil api yang dapat digunakan untuk memasak atau memanaskan. Dari hasil pemilihan tersebut diperoleh 1.157 unit dari berbagai jenis produk yang proses memasak atau memanaskannya serupa dengan Gasmin (lihat Gambar 2).

Dari hasil rekapitulasi data IKM tersebut, selanjutnya terpilih kembali sebanyak 517 unit IKM yang dianggap memenuhi kriteria untuk menggunakan Gasmin sebagai pasar potensial. Kelompok makanan dan minuman (mamin) merupakan industri yang paling banyak memanfaatkan api sebagai alat untuk memasak atau memanaskan (215 unit), disusul industri kerajinan batik (139) dan gerabah (56 unit). Potensi pasar Gasmin terbesar adalah Bantul sebanyak 200 unit, Sleman 174 unit, sedangkan Gunung Kidul, Yogya dan Kulon Progo masingmasing 60 dan 57 unit (lihat Tabel 2).

\section{Penentuan Sampel}

Populasi dalam penelitian ini adalah seluruh konsumen (IKM) yang memenuhi kriteria 
Gasmin yaitu sebanyak 517 unit (IKM). Pengambilan sampel dilakukan dengan menggunakan metode non-probabilitas yaitu menggunakan teknik Purposive Sampling. Sampel diambil berdasarkan kriteria tertentu.

Cara untuk menghitung sampel didasarkan pada rumus Slovin sebagai berikut:

$\mathrm{n}=\frac{\mathrm{N}}{1+\mathrm{Ne}^{2}}$

dalam hal ini,

$\mathrm{n}=$ ukuran sampel

$\mathrm{N}=$ ukuran populasi

e $=$ persentase tingkat kesalahan pengambilan sampel sebesar $8,1 \%$

$$
\mathrm{n}=\frac{517}{1+517(0,081)^{2}}=115
$$

artinya bahwa dalam melakukan penelitian pengukuran pasar Gasmin di DIY maka direkomendasikan untuk mengambil sampel (n) sebanyak 115 orang atau 115 unit usaha
(IKM) dari populasi yang jumlahnya 517 unit usaha.

\section{Analisis Pengukuran Pasar}

Berdasarkan hasil Pengukuran pasar dengan menggunakan metode FGD, pengamatan langsung ke lokasi, dan wawancara dengan responden menggunakan bantuan kuesioner, hasilnya disajikan pada uraian berikut.

1) Pasar Potensial :

Pasar yang sesuai dengan kriteria pengguna gasmin yaitu padat energi, pengguna boiler, pengguna oven pengering, pengguna BBM dan gas, dan proses memasak yang kontinyu (minimal 5 jam), sebagaimana ditunjukkan pada Tabel 1.

Dari Tabel 1 terlihat bahwa jumlah pasar potensial sebesar 517 unit usaha yang terdiri dari jenis Mamin sebesar 215 unit, Batik 139 unit, Gerabah 56 unit, Pandai besi 34 unit, Bata/Genteng 8 unit, Pembakaran kapur 5 unit dan peleburan alumunium sebesar 60 unit.

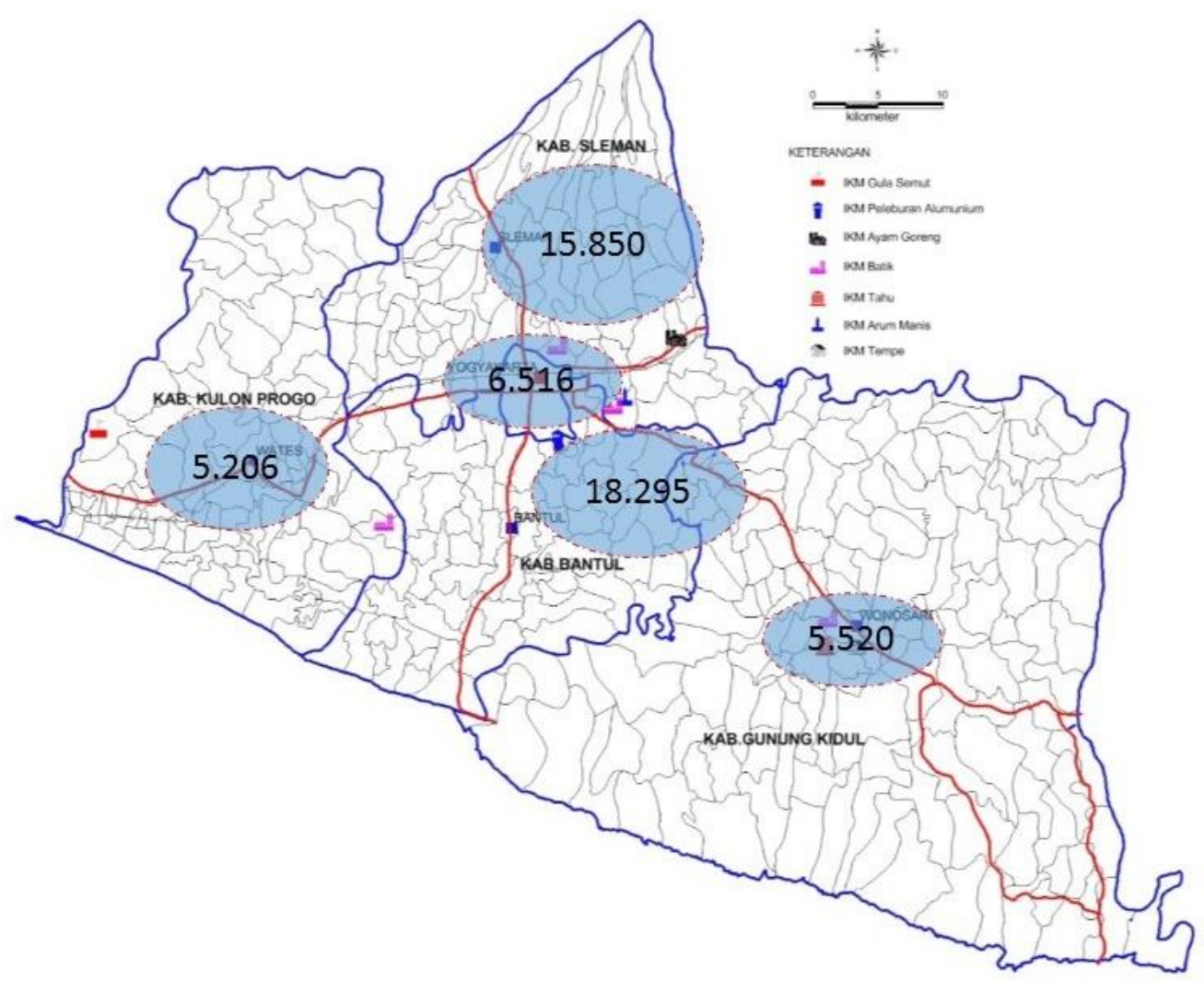

Sumber : Dinas Perindustrian dan Perdagangan Daerah Istimewa Yogyakarta (2017).

Gambar 1. Jumlah IKM di setiap kota dan kabupaten di DIY tahun 2017 (unit) 


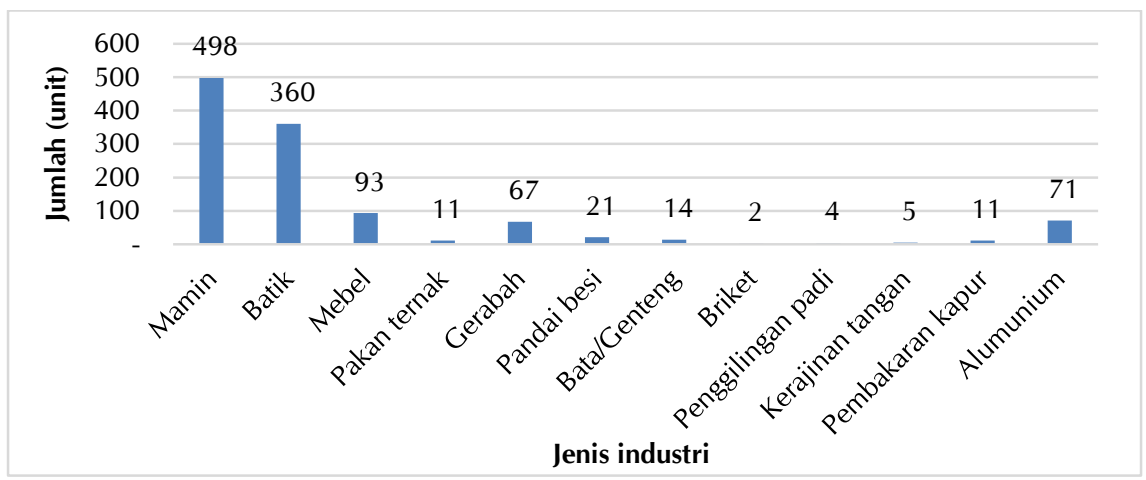

Sumber : Dinas Perindustrian dan Perdagangan Daerah Istimewa Yogyakarta (2017).

Gambar 2. Jumlah jenis IKM yang dikategorikan dapat menggunakan Gasmin (unit)

Tabel 1. Pasar pontesial IKM pengguna Gasmin batubara menurut jenis industri di DI Yogyakarta

\begin{tabular}{lcccccr}
\hline \multirow{2}{*}{ Jenis IKM } & \multicolumn{5}{c}{ Pasar potensial Gasmin (buah) } \\
\cline { 2 - 6 } & Sleman & Bantul & Kulon Progo & Gunung Kidul & Yogya & Jumlah \\
\hline Makanan dan Minuman & 107 & 54 & 27 & 27 & 215 \\
Batik & 59 & 42 & 10 & 28 & 139 \\
Gerabah & & 56 & & & 56 \\
Pandai besi & & 32 & 2 & 5 & 34 \\
Bata/Genteng & & 8 & & 60 & 60 \\
Pembakaran kapur & & & & 60 & 60 & 517 \\
Peleburan alumunium & & & 47 & & \\
\hline \multicolumn{1}{c}{ Total } & 166 & 184 & & & \\
\hline
\end{tabular}

Sumber : Dinas Perindustrian dan Perdagangan Daerah Istimewa Yogyakarta (2017).

2) Pasar yang tersedia.

Berdasarkan hasil kuesioner yang dibagikan pada saat FGD, diketahui bahwa Jumlah IKM yang berminat dan mempunyai pendapatan/kemampuan untuk membeli Gasmin adalah sebanyak 53 buah, yang terdiri dari jenis IKM batik, makanan/ minuman, batubata/genteng, pengolahan kayu, briket, pembakaran kapur, pengolahan susu dan peleburan alumunium (Tabel 2).

Tabel 2. Hasil jajak pendapat IKM peserta FGD terhadap Gasmin (unit usaha)

\begin{tabular}{lccccc}
\hline \multicolumn{1}{c}{ Jenis IKM } & $\begin{array}{c}\text { Tertarik, Ingin dan } \\
\text { Bersedia }\end{array}$ & $\begin{array}{c}\text { Tertarik dan } \\
\text { Ingin Memiliki }\end{array}$ & Tertarik & Tidak & Jumlah \\
\hline Batik & 3 & 9 & 11 & 10 & 33 \\
Makanan \& Minuman (tahu, & 15 & 12 & 7 & 17 & 51 \\
tempe, gula semut, kripik) & 6 & 2 & 2 & 3 & 13 \\
Batubata/ Genteng & - & - & - & 2 & 2 \\
Kerajinan tangan & - & 2 & 1 & 2 & 5 \\
Pengolahan kayu/ mebel & - & 1 & - & - & 1 \\
Briket & - & - & - & 5 & 5 \\
Pande besi & - & - & - & 1 & 1 \\
Penggilingan padi & 1 & - & - & - & 1 \\
Batubata/genteng & 1 & - & - & 1 & 2 \\
Pengolahan susu & 1 & - & - & - & 1 \\
Peleburan alumunium & 27 & 26 & 21 & 41 & 115 \\
\hline Total & & & & & \\
\hline
\end{tabular}

Sumber : Hasil survei tim Pemasaran Gasmin, Puslitbang Tekmira tahun 2016. 
3) Pasar yang tersedia yang memenuhi syarat Setelah diketahui pasar yang tersedia, selanjutnya dilakukan survei langsung ke lapangan untuk mengetahui aksesibilitas dan kualifikasi IKM ke lokasi langsung. Dari hasil survei langsung diperoleh jumlah dan jenis IKM yang memenuhi syarat dari aksesiblitas dan kualifikasi IKM sebanyak 25 IKM, yang terdiri dari perajin batik 8 unit, IKM makanan/minuman 11 unit, batubata/genteng 3 unit, pengolahan kayu 1 unit, pengolahan susu 1 unit dan peleburan alumunium 1 unit.

4) Pasar yang dilayani atau pasar sasaran, yaitu bagian dari qualified available market yang ingin dilayani.

Dari hasil pengukuran pasar yang tersedia, yang memenuhi syarat sebesar 10 IKM, maka pasar yang ingin dilayani adalah makanan/minuman sebanyak 5 unit, Batik 4 unit, dan 1 unit peleburan alumunium.

5) Pasar yang dipenetrasi,

Dari pasar yang ingin dilayani sebanyak 3 . unit, tetapi hanya satu industri tempe saja yang benar-benar telah melakukan pembelian

\section{HASIL DAN PEMBAHASAN}

Sebagaimana telah dijelaskan terdahulu, Gasmin batubara adalah suatu produk baru dan belum banyak yang mengetahui bagaimana produk tersebut bekerja dan menghasilkan api sehingga dapat digunakan untuk memasak atau memanaskan. Selain itu, produk ini memiliki karakteristik fisik yang sangat mencolok yaitu ukurannya besar, berat dan memerlukan ruang yang cukup luas sehingga tidak mudah untuk memasarkan dan memperkenalkan produk ini ke IKM secara perorangan (door to door). IKM yang dijadikan sasaran pun harus memiliki kriteria sebagai berikut: padat energi, pengguna boiler, pengguna oven pengering, pengguna kayu bakar, solar dan gas serta proses memasak yang kontinyu (minimal 8 jam). Namun, Dinas Perindustrian dan Perdagangan Provinsi DIY tidak memiliki data IKM sesuai dengan kriteria dimaksud. Sehingga diambil keputusan untuk mengundang para IKM dalam jumlah tertentu melalui kelompok diskusi terfokus (focus group discussion) untuk memperkenalkan dan memasarkannya. Para peserta diberikan penjelasan mengenai cara kerja produk secara visual, kunjungan ke tempat IKM yang sudah memiliki Gasmin kemudian para peserta diberikan lembar pertanyaan. Beberapa pertanyaan di antaranya menyangkut pendapatan yang diperoleh dari usaha dan minat peserta terhadap gasmin. Hal ini dimaksudkan untuk mengetahui minat dan kemampuan IKM untuk memiliki dan membeli Gasmin batubara. Pertanyaan lainnya menyangkut hal-hal yang berkaitan dengan kriteria Gasmin yang dimiliki oleh IKM. Jawaban peserta yang ada dalam pertanyaan tersebut kemudian disusun dalam bentuk tabulasi, dievaluasi dan dianalisis.

Jumlah peserta yang ikut menghadiri sosialisasi dan pemasaran yang dilaksanakan melalui kegiatan kelompok diskusi terfokus sebanyak 115 orang pengusaha dari berbagai jenis usaha. 44 orang peserta dari Sleman, 26 orang peserta dari Bantul, 11 orang peserta dari Gunung Kidul dan 34 orang dari Kulonprogo. IKM yang bergerak di bidang usaha makanan/minuman adalah peserta yang paling banyak yaitu 53 orang, diikuti oleh usaha batik 33 orang, batubata/gerabah 8 orang. Pandai besi dan meubel masing-masing 5 orang, kerajinan tangan 2 orang dan sisanya masingmasing 1 orang (Gambar 3). Sedangkan di Kota Yogyakarta tidak dilakukan FGD karena kawasan utama di kota ini yaitu kawasan peleburan alumunium, data potensi pasarnya sudah tersedia, yaitu 36 unit usaha dari 60 unit usaha yang aktif.

Berdasarkan hasil penyelenggaraan FGD, diperoleh informasi bahwa ada 41 peserta yang tidak tertarik dengan Gasmin batubara, 21 peserta tertarik tetapi tidak berminat untuk memiliki atau membeli dan 53 peserta tertarik dan ingin memiliki atau membeli. Dari jumlah 53 orang tersebut, 28 peserta di antaranya adalah pengusaha di bidang makanan/ minuman. 12 peserta dari usaha batik, batubata/genteng/gerabah sebanyak 8 peserta, 2 peserta mebel dan briket, pembakaran kapur, pakan ternak masing-masing satu peserta. 


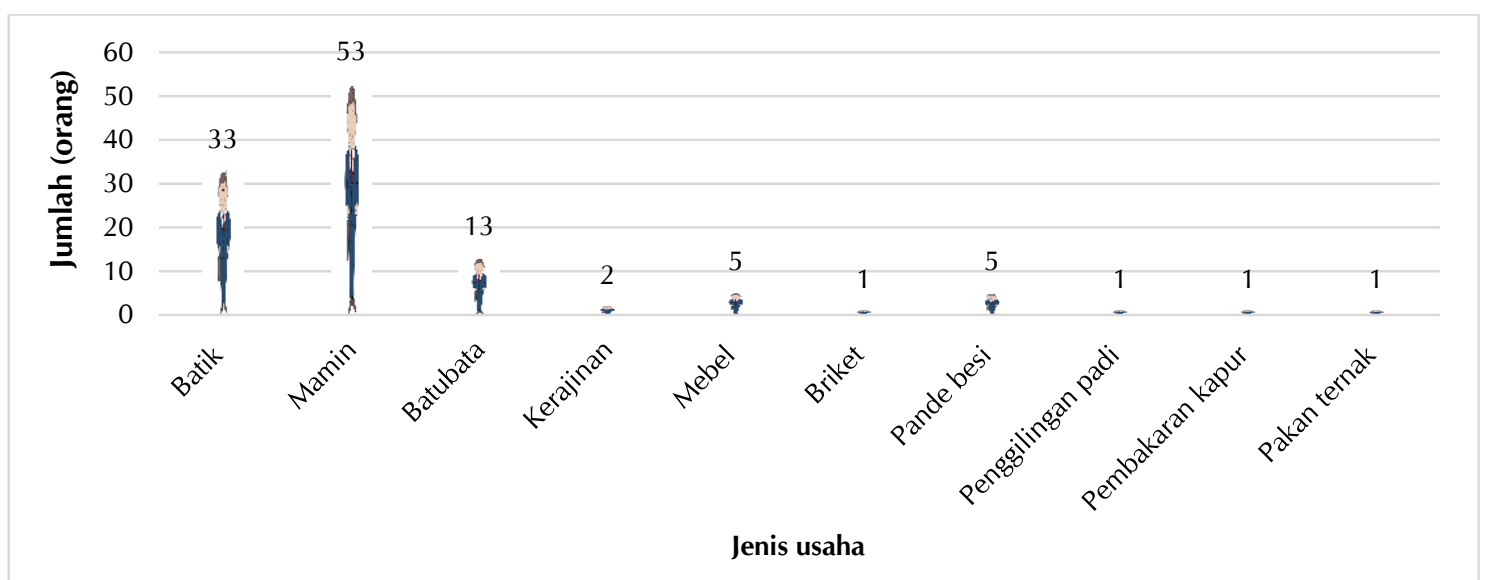

Sumber : Dinas Perindustrian dan Perdagangan Daerah Istimewa Yogyakarta (2017), diolah kembali.

Gambar 3. Peserta sosialisasi dan komersialisasi Gasmin di D.I. Yogyakarta

\section{Pasar IKM Perajin Batik}

Terdapat 12 peserta usaha batik yang berminat untuk membeli. Walaupun masih ada yang menggunakan bahan bakar kayu namun ada 8 perajin batik yang menggunakan gas sebagai bahan bakarnya. Biasanya mereka menghabiskan sebanyak 3 tabung berukuran @ 3 kg per minggu. Produksi kain batik yang akan dicelup rata-rata kurang dari 20 potong saja dalam setiap kali plorotan. Istilah plorotan adalah kain yang sudah dibatik dan diwarnai dimasukkan ke dalam air mendidih. Kegiatan plorotan inipun tidak dilakukan setiap hari, tergantung dari jumlah pemesanan. Keuntungan yang diperoleh dari hasil penjualan batik rata-rata kurang dari Rp.300.000 per hari. Dari delapan pengusaha tersebut, enam tempat usaha di antaranya berada di lokasi yang padat penduduk dan luas usahanya kurang dari 7 meter persegi, sedangkan 4 usaha batik lainnya berada di lokasi yang jarang penduduk dengan lahan yang cukup luas. Dengan demikian ada 4 perajin batik dari 12 perajin yang menjadi pasar potensial Gasmin batubara. Walaupun mereka berminat untuk memiliki, namun dengan harga Gasmin yang ditawarkan sebesar Rp. 70 juta bagi mereka dinilai terlalu mahal. Mereka mengharapkan adanya keringanan harga dan juga cicilannya.

Berdasarkan hasil analisis di atas, maka pasar Gasmin batubara yang ingin dilayani pada industri perajin batik adalah $4 / 12=1 / 3$ atau sekitar 0,33. Jika jumlah perajin batik di DIY yang memenuhi kriteria Gasmin sebanyak 139 unit (Tabel 1), maka pasar Gasmin batubara yang benar-benar yang ingin dilayani adalah $1 / 3$ x 139 unit $=$ 46,33 dibulatkan menjadi 46 unit.

\section{Pasar IKM Makanan/Minuman}

Dari 53 peserta usaha makanan/minuman yang mengikuti FGD, ternyata yang berminat untuk memiliki sebanyak 28 orang. Namun dari 28 peserta tersebut hanya 2 peserta saja yang dinilai dapat memenuhi kriteria efisiensi penggunaan Gasmin, sedangkan 26 peserta lainnya menghabiskan bahan bakar antara Rp. 14.000 sampai dengan Rp. 117.000 per hari. Selain tidak memiliki lahan yang cukup untuk menyimpan Gasmin, lokasinya juga berada di area yang padat penduduk, sehingga tidak memungkinkan dipasang Gasmin batubara karena asap hasil gasifikasi dapat menganggu lingkungan sekitar.

Berdasarkan hasil analisis di atas, maka pasar Gasmin batubara pada industri makanan/ minuman yang benar-benar ingin dilayani adalah $2 / 28=0,07$. Jumlah usaha makanan/ minuman di DIY yang memenuhi kriteria Gasmin sebanyak 215 unit (Tabel 1), maka potensi pasar Gasmin batubara adalah 0,07 X 215 unit $=0,07$ dibulatkan menjadi 15 unit. Dalam melakukan proses produksi, usaha ini menggunakan gas sebagai bahan bakarnya. Apabila usaha ini menggunakan Gasmin, maka panas yang dihasilkan oleh Gasmin ini harus setara dengan panas yang dihasikan oleh gas yang bisa diatur dengan alat pengatur besar dan kecilnya api sesuai dengan keperluan. Selama ini, produk api yang dihasilkan melalui 
proses gasifikasi ini berupa lidah api yang besar, sehingga untuk meraih pasar Gasmin di IKM makanan/minuman harus dibuat suatu sistem pengaturan pengeluaran api yang sesuai dengan karakteristik gas (LPG) yang saat ini digunakan di tempat usaha makanan/ minuman. Harga masih menjadi kendala bagi pengusaha makanan/minuman untuk memiliki alat ini sebagai pendukung kegiatan produksinya. Mereka mengharapkan adanya bantuan dari pemerintah mengingat keuntungan dari usaha mereka belum mampu untuk membelinya.

\section{Pasar Gasmin di DIY}

Potensi pasar Gasmin batubara pada usaha batik sebanyak 46 unit dari 219 unit yang ada di Daerah Istimewa Yogyakarta, sedangkan pada usaha makanan/minuman hanya 15 unit saja dari 215 unit yang ada. Sedangkan potensi pasar pada usaha pengrajin alumunium sebanyak 36 unit, sehingga jumlahnya keseluruhan sebanyak 97 unit saja yang benarbenar akan dilayani dan dijadikan sasaran pasar Gasmin batubara. Usaha pembakaran batubata/gerabah, walaupun ada 8 peserta yang berminat untuk memiliki ternyata sistem pembakarannya tidak sesuai dengan karakteristik pembakaran yang dimiliki oleh Gasmin, sehingga dianggap bukan menjadi taget pasar Gasmin. Demikian juga untuk pengolahan kayu, briket dan pembakaran kapur.

\section{Pemasok Batubara}

Mengingat batubara adalah bahan bakar utama beroperasinya Gasmin, maka ketersediaan batubara merupakan hal yang mutlak. Oleh karena itu, harus ada suatu lembaga/ perusahaan, maupun perorangan yang mampu mengelola batubara mulai dari pengadaan dan pendistribusiannya (distributor). Model pengelolaan batubara dapat dilakukan:

1. melalui pembelian ke pemasok di tiga daerah tersebut, kemudian dikirim langsung ke masing-masing IKM pengguna Gasmin sesuai dengan jumlah pemesanan,

2. dengan membangun gudang di pusat kota yaitu di Yogya, kemudian pengiriman dilakukan ke berbagai wilayah IKM yang memesan batubara, atau

3. dengan membangun dan menyimpannya di suatu gudang/depo di setiap kabupaten/kota untuk kemudian didistribusikan ke berbagai lokasi IKM pengguna Gasmin sesuai jumlah pemesanan.

Ada lima daerah yang diusulkan menjadi pemasok batubara untuk IKM pengguna Gasmin batubara di DI Yogyakarta yaitu PT. GAC di Cirebon, Jawa Barat, PT. MBS (Demak), PT.MSJ (Semarang), PT. BAP (Kendal) dan PT. RBI di Karanganyar, Jawa Tengah.

Batubara yang ada di pemasok didatangkan dari lokasi tambang di Kalimantan Selatan dan Kalimantan Timur melalui Pelabuhan Cirebon, Jawa Barat dan Pelabuhan Mas Semarang, Jawa Tengah. Batubara di setiap pemasok sangat terjamin ketersediaannya, hal ini terbukti dari volume batubara di gudang (stockpile) yang dimiliki oleh masing-masing perusahaan pemasok batubara cukup melimpah dan selalu ada, bila suatu saat diperlukan.

\section{KESIMPULAN DAN SARAN}

\section{Kesimpulan}

Berdasarkan hasil pengukuran pasar Gasmin batubara di Daerah Istimewa Yogayakarta dapat disimpulkan:

1. Pasar Gasmin yang akan dilayani adalah sebesar 53 unit usaha, atau hanya sebesar $10,25 \%$ dari total pasar potensial sebesar 517 IKM, dan yang benar-benar telah melakukan pembelian (pasar yang dipenetrasi) sampai saat artikel ini ditulis hanya 1 IKM saja. Sebagian besar IKM tidak memenuhi kriteria penggunaan Gasmin karena tidak memiliki ruang yang cukup, terletak di lingkungan padat penduduk dan di jalan yang tidak bisa dilalui kendaraan roda 4.

2. Harga Gasmin menjadi kendala bagi IKM untuk memiliki Gasmin, karena sebagian besar pendapatan IKM sangat rendah.

3. Segmentasi pasar Gasmin hanya terbatas pada tiga jenis usaha, yaitu makanan/minuman, batik dan alumunium. Oleh karena itu, untuk memperluas peluang pasar sebaiknya teknologi Gasmin dapat dikembangkan sesuai dengan kondisi pasar konsumen.

4. Pasar Gasmin untuk IKM yang bergerak di bidang makanan dan minuman cukup 
besar, tetapi penggunaan rata-rata maksimal 4 jam per hari dan membutuhkan suhu relatif rendah.

\section{Saran}

1. Mahalnya harga Gasmin menjadi salah satu kendala bagi IKM yang meminatinya, sehingga harus ada model pembelian yang dapat meringankan mereka. Salah satunya adalah dengan menawarkan pembelian tanpa uang muka dengan cicilan yang ringan atau dengan bantuan uang muka dari pemerintah/subsidi sehingga sisa pembayaran diangsur oleh mereka.

2. Memperluas target pasar Gasmin batubara ke segmentasi pasar yang lebih sesuai dengan kriteria Gasmin batubara atau pemasaran dilakukan ke daerah lain untuk mendapatkan pasar yang diinginkan.

\section{UCAPAN TERIMA KASIH}

Pada kesempatan ini, ucapan terima kasih disampaikan kepada semua pihak lembaga/instansi maupun pribadi yang telah memberikan saran dan masukan, baik langsung maupun tidak langsung sehingga terwujudnya hasil kajian ini dan semoga pula kajian ini bermanfaat bagi para pelaku usaha mineral logam, peneliti dan pemerhati mineral logam.

\section{DAFTAR PUSTAKA}

Adawiyah, R. (2012) Laporan praktikum pemasaran: Membuat kuesioner dan riset pasar. Universitas Gadjah Mada.

BPS (2016) Statistik industri di DIY. Yogyakarta: Badan Pusat Statistik.

Dewanti, R. dan Sihombing, G. (2012) "Analisis pendapatan usaha peternakan ayam buras (Studi kasus di Kecamatan Tegalombo, Kabupaten Pacitan)," Buletin Peternakan, 36(1), hal. 48 doi: 10.21059/buletinpeternak.v36i1.1276.

Dinas Perindustrian dan Perdagangan Daerah Istimewa Yogyakarta (2017) Direktori industri kecil dan menengah Daerah Istimewa Yogyakarta. Yogyakarta: Dinas Perindustrian dan Perdagangan Daerah Istimewa Yogyakarta.
Marshal, R. (2012) "Penerapan energi efisiensi di IKM," in Workshop Efisiensi Energi di Sektor Industri Kecil dan Menengah. Jakarta.

Pebriani, Y. S. (2016) Pengaruh persepsi konsumen terhadap keputusan pembelian produk merek pribadi. Universitas Lampung.

Rakhman, H. Y. (2016) Analisis persepsi konsumen terhadap produk rokok Fit Mild Bright di wilayah perkotaan Kab. Jember (Studi empiris pada masyarakat perkotaan Kabupaten Jember). Universitas Lampung.

Sofaeti, Y., Daulay, B., Efendi, M. A. A., Sulistyohadi, F., Hudaya, G. K., Monika, I., Saputra, R., Yusnanto dan Ropik (2015) Implementasi pengembangan gasifier batubara di IKM untuk peleburan alumunium dan industri yang menggunakan boiler. Bandung: Puslitbang tekMIRA.

Sugiyanto, H. (2017) "The causality between energy consumption and gross domestic product (GDP) in Indonesia, Malaysia, Thailand and Singapore," Jurnal Info Artha, 1(2), hal. 79-90.

Suprapto, S. (2014) "Gasifikasi batubara, solusi di tengah berlimpahnya batubara Indonesia," in Karakteristik dan Pemanfaatan Batu Bara: Solusi dalam Keberlimpahan Batu Bara di Indonesia. Jakarta: Badan Litbang ESDM, hal. 43-67.

Susetyarsi, T. (2014) "Analisis daya tarik sumber iklan dan pengaruhnya terhadap minat beli konsumen pada produk minuman suplemen merek kuku bima energi di kota Semarang," Jurnal STIE Semarang, 6(3), hal. 120-138.

Trifiananto, M. (2015) Karakterisasi gasifikasi batubara tipe updraft dengan variasi equivalence ratio. Institut Technology Sepuluh Nopember.

Wati, R., Sari, P., Assagaff, S. Y. A. S., Turna, L. A., Karanelan, C. dan Sumaryadi (2013) Perencanaan pemasaran korporat dan analisis pasar dan pengukuran pasar. Universitas Pattimura.

Wijayanti, P. S., Ispriyanti, D. dan Wuryandari, T. (2013) "Pengambilan sampel berdasarkan peringkat pada analisis regresi linier sederhana," Jurnal Gaussian, 2(3), hal. 209218.

Yusra, I. (2018) Gasifikasi batubara, www.academia.edu. 